\title{
Rensch's rule is broken in Cervidae
}

\author{
Talita Ferreira Amado ${ }^{1,2}$ (D), Claudio Juan Bidau ${ }^{3}$ (D), Juan Pablo Zurano ${ }^{4}$ (D), \\ Vanina Raimondi ${ }^{5}$, Gabriel Costa ${ }^{6}$ (D) \& Pablo Ariel Martinez ${ }^{2,7}$
}

(1) Rey Juan Carlos University, Department of Biology and Geology, Physics and Inorganic Chemistry, Biodiversity and Macroecology Laboratory, Móstoles 28933, Madrid, Spain. E-mail: amadotalita@gmail.com

(2) Universidade Federal de Sergipe, Centro de Ciências Biológicas e da Saúde, Departamento de Biologia, Cidade Universitária Prof. José Aloísio de Campos, Av. Marechal Rondon, Jardim Rosa Elze, São Cristóvão 49100-000, Sergipe, Brazil. E-mail: pablo_sc82@ hotmail.com

(3) Paraná y los Claveles, Buenos Aires, Argentina.

(4) Universidade Federal da Paraíba, Centro de Ciências Exatas e da Natureza, Departamento de Sistemática e Ecologia, Programa de Pós-Graduação em Ciências Biológicas (Zoologia), Cidade Universitária 58051-900, João Pessoa, Paraíba, Brazil. E-mail: zuranojp@gmail.com

(5) Université de Genève, Department of Genetics and Evolution, Quai Ernest-Ansermet 30, Geneve 1205, Switzerland. E-mail: vanina.raimondi@etu.unige.ch

(6) Auburn University at Montgomery, Department of Biology and Environmental Sciences, Montgomery, AL 36124, USA. E-mail: gcosta@aum.com

(7) Universidade Federal de Sergipe, Centro de Ciências Biológicas e da Saúde, Departamento de Ecologia, Programa de pós-graduação em Ecologia e Conservação, Cidade Universitária Prof. José Aloísio de Campos, Av. Marechal Rondon, Jardim Rosa Elze, São Cristóvão 49100-000, Sergipe, Brazil.

Amado T.F., Bidau C.J., Zurano J.P., Raimondi V., Costa G. \& Martinez P.A. (2019) Rensch's rule is broken in Cervidae. Pesquisa e Ensino em Ciências Exatas e da Natureza, 3(2): 134-141.

http://dx.doi.org/10.29215/pecen.v3i2.1259

Academic editor: Paulo Roberto Medeiros. Received: 19 July 2018. Accepted: 19 August 2019. Published: 02 October 2019.

\section{A regra de Rensch está quebrada em Cervidae}

Resumo: A diferença de tamanho corporal entre machos e fêmeas é conhecida como dimorfismo sexual de tamanho (DST). O surgimento do DST é atribuído na maioria das vezes a processos de seleção sexual, entretanto a seleção natural também pode afetar o DST. Tem se observado em diversos grupos que a intensidade do DST está associada com o tamanho corporal das espécies, padrão conhecido como Regra de Rensch. Nós testamos a regra de Rensch na família Cervidae, um grupo com forte dimorfismo sexual. Analisamos o DST de 35 espécies utilizando análises de regressão tipo II (eixo principal reduzido) filogenética (RMA). Ao analisar a relação entre o tamanho dos machos vs o tamanho das fêmeas observamos que o DST se modifica isometricamente com o aumento do tamanho corporal ( $\beta$ RMA $=1.05, p$ $=0.18$. Estes resultados evidenciam que a regra de Rensch não se cumpre nos membros da família Cervidae. Na última década, diversos estudos tem mostrado grupos taxonômicos que não seguem a regra de Rensch. Dado que o tamanho corporal está associado com diversas características ecológicas das espécies, é possível que a associação do tamanho corporal com o DST não seja sempre um efeito causal nos grupos que seguem a Regra de Rensch.

Palavras chave: Dimorfismo sexual de tamanho, mamíferos, RMA filogenético, seleção sexual, tamanho corporal.

Abstract: The difference in body size between males and females is known as sexual size dimorphism (SSD). The existence of SSD is usually attributed to processes of sexual selection, although natural selection can also affect SSD. In some animal groups the extension of SSD is associated with body size, a pattern known 
as Rensch's rule. We tested Rensch's rule in the members of the family Cervidae, a group with strong sexual dimorphism. We analyzed SSD of 35 species by means of phylogenetic reduced major axis regression (RMA). Analyzing the relationships between male size vs female size we observed that SSD changes isometriclly with the increase of body size $(\beta \mathrm{RMA}=1.05, \mathrm{p}=0.18)$. These result evidence that Rensch's rule does not operate among members of the family Cervidae. In the last decade, many studies have shown diverse taxonomic groups that do not follow Rensch's rule. Because body size is associated with many ecological characteristics, it is possible that the association of body size with SSD is not always a causal effect in those groups that follow Rensch's rule.

Key words: Sexual size dimorphism, mammals, phylogenetic RMA, sexual selection, body size.

\section{Introduction}

Sexual dimorphism is widespread in the animal kingdom. Males and females may differ in most secondary sexual traits (e.g., body size and shape, colour, antlers, feathers and behaviour) and sexual selection acts on those traits by maximizing individual reproductive success while not necessarily increasing survivorship (Darwin 1859, 1871; Emlen et al. 2005; Plard et al. 2011; Fairbairn 2013). Thereby, natural selection has also an important role on sexual dimorphism by limiting the growth of sexual display traits, increasing the competition between sexes and increasing differences between the reproductive and ecological roles of males and females (Clutton-Brock et al. 1977; Pérez-Barbería et al. 2002; Stuart-Fox \& Ord 2004). Sexual size dimorphism (SSD) - the difference in body size between males and females of the same species is among the most conspicuous and widely studied sexual differences (Emlen et al. 2005; Isaac 2005; Tobias et al. 2012). The SSD (either male-biased or female-biased) is common and highly variable in the most diverse animal groups, and even closely related phylogenetic lineages may show strikingly different levels of SSD. Additionally, both conditions (male and female-biased SSD) may occur within the same lineage indicating a great lability of SSD (Fairbairn et al. 2007).

Body size is a highly variable characteristic both at the intra-specific (e.g., Martinez et al. 2013, 2018) and inter-specific levels (Smith \& Lyons 2011). Body size is strongly associated with multiple characteristics of the life history of organisms and is in turn affected by environmental (Peters 1983; Olalla-Tárraga et al. 2015; Gohli \& Voje 2016) and genetic factors (Martinez et al. 2018). SSD is not an expeption to these factors, many studies show that SSD may be associated with variation of body size (Fairbairn et al. 2007; Fairbairn 2013). As a result of this dependence, in species where males are larger than females, when species body size is increased, SSD also increases. In contrast, in species whose females are bigger than males the increase in body size would lead to a decrease of SSD (Rensch 1950; Fairbairn 1997). This pattern is known as "Rensch's rule" and could be a result of a differential response to selection on body size in females and males (Fairbairn 1997). However, no completely satisfactory model of Rensch's rule exists up to this day (Kappeler \& van Schaik 2004; Piross et al. 2019). Then, if Rensch's pattern is fulfilled, we expect a positive allometric association between SSD and body size. Body size is decisive for male success in polygenic species because bigger males are commonly the healthier, more aggressive and experienced ones (Miller 2013).

Understanding the mechanisms that modulate SSD is very relevant for the assessment of the evolutionary forces that drive species diversification. We analyzed SSD and the operation of Rensch's rule in Cervidae. We chose deer as a model system for the following reasons: data on male and female body size are available for many species, and the family present many obvious traits of male-biased sexual dimorphism as well as a variety of mating and social systems. We used phylogenetic comparative methods to analyse the relationship (scaling) between SSD data and body size for 35 cervid species.

\section{Material and Methods}

\section{Data collection}


We built a database of body mass for males (MBM) and females (FBM) of 35 cervid species (Table 1). We estimated SSD as $\log (\mathrm{MBM} / \mathrm{FBM}$ ) (Fairbairn 2007), where positive values represent a male bias of SSD and negative values represent a female bias of SSD.

Table 1. Body mass (kg) of male (MBM) and female (FBM) cervids species used in this study.

\begin{tabular}{|c|c|c|c|c|c|}
\hline Species & Common Name & MBM & FBM & LOG(M/F) & Reference \\
\hline Alces alces & Moose & 482.5 & 365 & 0.121204453 & Plard et al. (2011) \\
\hline Axis axis & Chital & 89.5 & 39 & 0.360758428 & Plard et al. (2011) \\
\hline Axis porcinus & Hog Deer & 41 & 31 & 0.121422163 & Plard et al. (2011) \\
\hline Capreolus capreolus & Western Roe Deer & 28 & 26.5 & 0.023912157 & Plard et al. (2011) \\
\hline Capreolus pygargus & Eastern Roe Deer & 42 & 39.5 & 0.026652195 & Plard et al. (2011) \\
\hline Cervus albirostris & White-Lipped Deer & 204 & 125 & 0.212720154 & Plard et al. (2011) \\
\hline Cervus canadensis & Wapiti & 350 & 250 & 0.146128036 & Plard et al. (2011) \\
\hline Cervus duvauchelii & Barasingha & 236 & 145 & 0.211544001 & Plard et al. (2011) \\
\hline Cervus elaphus & Red Deer & 250 & 125 & 0.301029996 & Plard et al. (2011) \\
\hline Cervus eldi & Eld's Deer & 105 & 67 & 0.195114496 & Plard et al. (2011) \\
\hline Cervus nippon & Sika Deer & 52 & 37 & 0.14780162 & Plard et al. (2011) \\
\hline Cervus timorensis & Timor Deer & 95.5 & 33 & 0.461489432 & Plard et al. (2011) \\
\hline Cervus unicolor & Sambar & 192 & 146 & 0.118948373 & Plard et al. (2011) \\
\hline Cervus mariannus & Philippine Deer & 64 & 40.4 & 0.199798609 & Wiles et al. (1999) \\
\hline Dama dama & Fallow Deer & 67 & 44 & 0.182622126 & Plard et al. (2011) \\
\hline Elaphodus cephalophus & Tufted Deer & 18 & 18 & 0 & Plard et al. (2011) \\
\hline Elaphodus davidianus & Pere David's Deer & 214 & 159 & 0.129016649 & Plard et al. (2011) \\
\hline Hippocamelus antisensis & Taruca & 65 & 45 & 0.159700843 & Barrio (2010) \\
\hline Hippocamelus bisculus & Chilean Guemal & 95 & 75 & 0.102662342 & Plard et al. (2011) \\
\hline Magammuntiacus vuquangensis & Giant Muntjac & 45 & 34 & 0.121733597 & Plard et al. (2011) \\
\hline Mazama americana & Red Brocket & 24.5 & 24.5 & 0 & Plard et al. (2011) \\
\hline Mazama goauzoupira & Gray Brocket & 18 & 18 & 0 & Plard et al. (2011) \\
\hline Mazama rufina & Dwarf Red Brocket & 12.5 & 12 & 0.017728767 & Barrio (2010) \\
\hline Moschus fuscus & Black Musk Deer & 12.5 & 13 & -0.017033339 & Nowak (1999) \\
\hline Muntiacus feae & Fea's Muntjac & 19.5 & 22 & -0.052388069 & Geist (1998) \\
\hline Muntiacus crinifrons & Black Muntjac & 23 & 24.1 & -0.020289207 & Plard et al. (2011) \\
\hline Muntiacus gonghanensis & Gongshan Muntjac & 21 & 16 & 0.118099312 & Plard et al. (2011) \\
\hline Muntiacus muntjak & Muntjac & 19 & 20 & -0.022276395 & Plard et al. (2011) \\
\hline Muntiacus putaoensis & Leaf Deer & 12 & 12 & 0 & Plard et al. (2011) \\
\hline Muntiacus reevesi & Chinese Muntjac & 13.5 & 14 & -0.015794267 & Plard et al. (2011) \\
\hline Muntiacus atherodes & Bornean Muntjac & 18 & 16 & 0.051152522 & Payne \& Francis (1985) \\
\hline Odocoileus hemionus & Mule Deer & 112.5 & 55.5 & 0.306859539 & Plard et al. (2011) \\
\hline Pudu puda & South Pudu Deer & 13 & 13.5 & -0.016390416 & Plard et al. (2011) \\
\hline Pudu mephistophiles & Northern Pudu & 13.16 & 13.84 & -0.021880201 & Geist (1998) \\
\hline Tragulus javanicus & Lesser Mouse-Deer & 2 & 1.5 & 0.124938737 & Geist (1998) \\
\hline
\end{tabular}

\section{Comparative analyses}

We performed a phylogenetic reduced major axis regression (RMA) analysis between $\log 10$ (MBS) and $\log 10$ (FBS), with the phytools package (Revell 2012) in R 3.2.2 (R Core Team 2018). If Rensch's rule is verified, the slope ( $\beta$ ) must be significantly higher than 1 , but if $\beta<1$ the rule is inverted, and if $\beta=1$ the rule is not supported (Abouheif \& Fairbairn 1997; Fairbairn 1997). Comparative methods allow us to correct for statistical non-independence of biological data (Felsenstein 1985). Due the non-independence of species-level data, the use of comparative methods is necessary. Additionally, the use of RMA is appropriate because ordinary model I regressions are inadequate when both variables (response and predictors) are estimated with errors (Fairbairn 1997). In this case, regression models of type II are the best and recommended option (Sokal \& Rohlf 1995).

To perform comparative analyses, we used the phylogenetic hypothesis from Hassanin et al. (2012). Since we have some species with size information that are not included in the phylogeny, we included them randomly from the genus node where they occur. This procedure was repeated 100 times, generating 100 phylogenetic trees and allowing us to account for phylogenetic uncertainty in our analyses (Rangel et al. 2015). Thus, the RMA phylogenetic 
analyses were conducted 100 times for each phylogenetic tree, as proposed by Martinez et al. (2015).

\section{Results}

\section{Data overview}

The body weight of analysed cervid species varied between 2 to $482.5 \mathrm{~kg}$ (mean $=87.70$ $\mathrm{kg}$ ) for males, and between 1.5 to $365 \mathrm{~kg}$ for females (mean = $60.58 \mathrm{~kg}$ ) (Table 1). We observed a strong prevalence of male-biased sexual dimorphism ( $70 \%$ of species). The highest male-biased SSD were found for Cervus timorensis (male $=95.5 \mathrm{~kg}$, female $=33 \mathrm{~kg}$ ). Conversely, from female-biased SSD species the difference between females and males were small, with the most dimorphic species being Muntiacus feae (male $=19.5 \mathrm{~kg}$, female $=22 \mathrm{~kg}$ ). When analysing the scaling of sexual dimorphism with body size, we found no evidence that SSD increases in relation to body mass in deer species. We analysed the relationship of $\log 10(\mathrm{MBM})$ versus $\log 10$ (FBM) and from these results we observed a mean of $\beta$ RMA equal to 1.05 ( $p=0.18$ ) (Figure 1). This result do not support Rensch's rule in cervids.

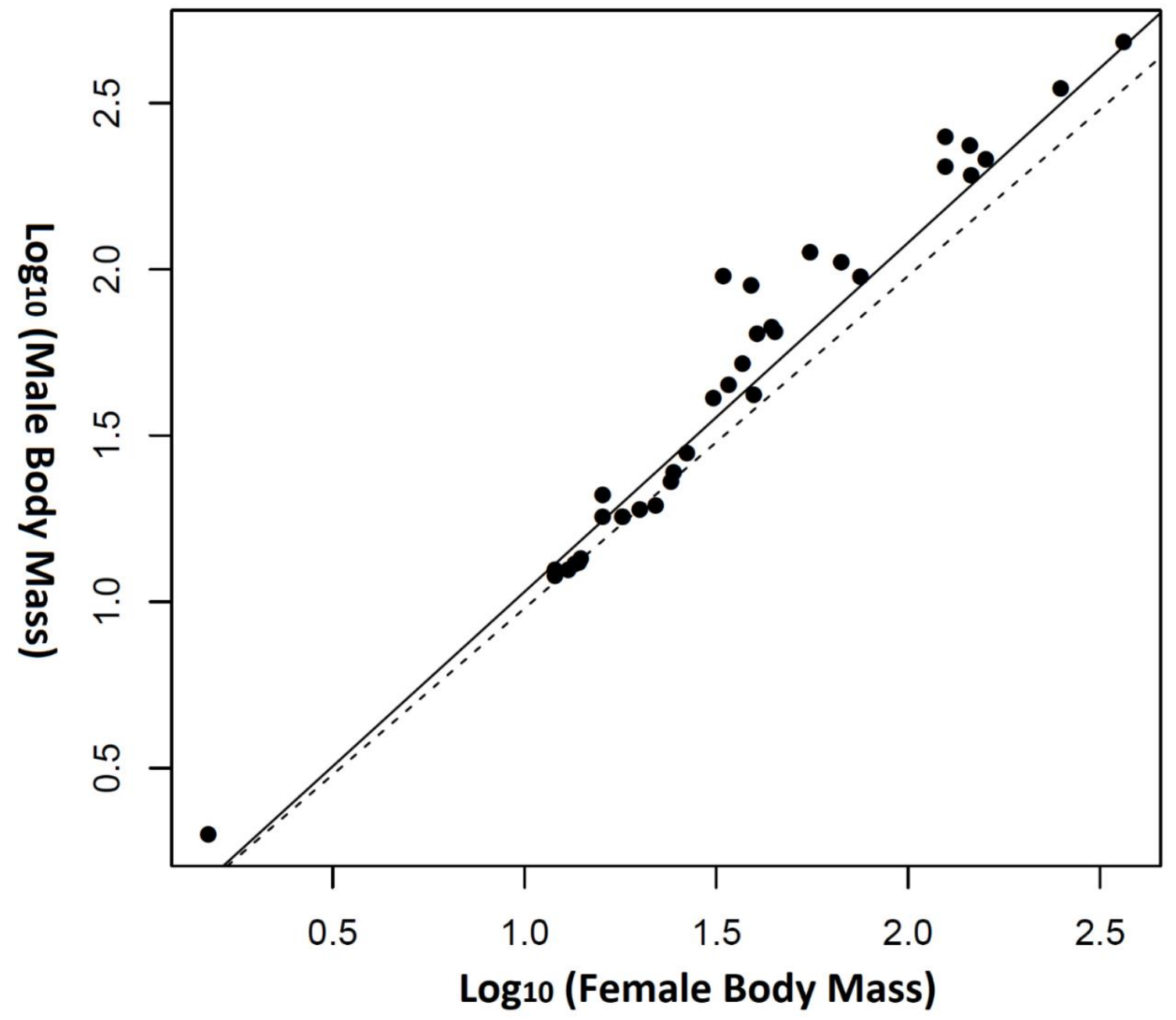

Figure 1. Reduced Major Axis (RMA) regressions between male body mass (log10) vs female body mass $(\log 10)$ of 35 species of cervids. The solid line show the slope of regression and dashed line show de slope $=$ 1.

\section{Discussion}

Our results showed that cervids display a large variation in body size and SSD. Because of the predominance of male-biased SSD we expected that, if Rensch's rule operates in this 
family, a hyperallometric relationship between male and female size $(\beta>1.0)$ indicating an increase in SSD with increasing body size. Nevertheless, our results showed an isometric relationship ( $\beta=1.0$ ) which means that SSD does not scale with body size in cervids which in consequence do not follow Rensch's rule.

Most mammal species show male-biased SSD (Fairbairn 2007). As known, sexual selection could not only drive SSD, but also be responsible for a significant fraction of the evolution of male bias (Jarman 1983; Isaac 2005; McPherson \& Chenoweth 2012). The pattern recognized as Rensch's rule proposes that SSD increases when the body size in a male-biased species also increases (Rensch 1950; Abouheif \& Fairbairn 1997). However, our results indicate that there is no significant increment in SSD with body size growth. Although some comparative analyses suggest the opposite (Abouheif \& Fairbairn 1997; Fairbairn 1997, 2007), Rensch's rule has been widely questioned due the lack of clear mechanisms that may explain this pattern (Reiss 1989; Fairbairn 2013).

Different hypotheses were proposed to account for the covariation between SSD and body size (Martinez \& Bidau 2016). Many studies that attempted to find evidences for Rensch's rule have serious methodological flaws and inappropriate statistical analyses (Abouheif \& Fairbairn 1997). As proposed by many biologists, allometry consistent with Rensch's rule evolves as a response to sexual selection of male size (Fairbairn 1997, 2007, 2013). Thus, selection will happen more often in taxa with male biased size, as in cervids. Nevertheless, the rule lacks in consistency and the reproductive success of larger males may not increase the size difference between of males and females. Alternatively, some researchers suggest that SSD would emerge due a correlated evolutionary response in one sex to stronger sexual selection in another sex (Dale et al. 2007). In this case, SSD evolves as a by-product of genetic differences between males and females and their different responses to similar selective pressures. Another possible explaination is when females and males use different resources, being the natural selection the force that promotes the differentiation (Fairbairn 1997). When exist a strong stabilizing selection on female body size than on male size can lead to increased SSD when resources are plentiful, independent of sexual selection (Colwell 2000). Therefore, our fail to detect this pattern in extant species may due to our inability to directly analyse these differences between males and females across lineages (Blanckenhorn et al. 2007).

Rensch's rule is thus strongly controversial and numerous exceptions exist in mammals (e.g., Canidae, Felidae, Ctenomyidae) (Lindenfors et al. 2007; Martinez et al. 2014; Martinez \& Bidau 2016; Stevens \& Platt 2015; Bidau \& Martinez 2017). The trend to follow or not Rensch's rule seems not to be phylogenetically structured. This is evident in some recent studies of domesticated animals. In a recent study, Bidau \& Martínez (2017) showed that domesticated mammals such as dogs and cats, follow Rensch's rule while their ancestors (species of Canidae and Felidae) do not. Possible reason for the existence of taxa that follow Rensch's rule and other that do not may be the intrinsic complexity of the regulation of body size. Body size has a strong phylogenetic component (Diniz-Filho et al. 2007) but it is also deeply affected by natural and sexual selection (Smith \& Lyons 2013). Furthermore, the size of a species is related to many ecological traits (e.g. number of offspring, home range, thermal tolerance, number of parasites) (Morand \& Poulin 1998; Olalla-Tárraga et al. 2015). In carnivores for example, the number of parasites can increase SSD (Huang et al. 2015), while species with larger body size may also host more parasites (Morand \& Poulin 1998). The association of body size with multiple ecological traits may lead reserachers to find an association between body size and SSD. However, these relationships not necessarily indicate that body size affects the species SSD. In this sense, studies of Rensch's rule must consider the direct and indirect effects of body size on SSD. Thus, an alternative to this approach is to use ecological characteristics jointly with body size to understand the ultimate causes that modulate SSD. 


\section{Acknowledgements}

TFA and PAM would like to thank CAPES and CNPq for the funding support of this work, grants 202116/2014-0 and 200557/2014-9, respectively. G.C.C. thanks CNPq grants 474392/2013-9, 201413/2014-0 and 302776/2012-5. We dedicate this work to Dr Claudio Bidau. His achievements in life and science will continue to inspire us.

\section{References}

Abouheif E. \& Fairbairn D.J. (1997) A Comparative Analysis of Allometry for sexual Size Dimorphism: Assessinf Rensch's Rule. The American Naturalist, 149(3): 540-562. DOI: $10.1086 / 286004$

Andersson M. (1994) Sexual Selection. Princeton: University Press. 624 p.

Barrio J. (2010) TARUKA Hippocamelus antisensis (d'Orbigny 1834) (p. 77-88). In: Duarte J.M.B. \& González S. (Eds). Neotropical Cervidology: Biology and medicine of Latin American deer. Jaboticabal, Brazil: Funep; Gland, Switzerland: IUCN. 393 p.

Blanckenhorn W.U., Dixon A.F.G., Fairbairn D.J., Foellmer M.W., Gibert P., van der Linde K., Meier R., Nylin S., Pitnick S., Schoff C., Signorelli M., Teder T. \& Wiklund C. (2007) Proximate Causes of Rensch's Rule: Does Sexual Size Dimorphism in Arthropods Result from Sex Differences in Development Time? The American Naturalist, 169(2): 245-257. DOI: $10.1086 / 510597$

Bidau C.J. \& Martinez P.A. (2017) Cats and dogs cross the line: domestic breeds follow Rensch's rule, their wild relatives do not. Vavilovskii Zhurnal Genetiki i Selektsii = Vavilov Journal of Genetics and Breeding, 21(4): 443-451. DOI: 10.18699/VJ17.263

Clutton-Brock T., Harvey P. \& Rudder B. (1977) Sexual dimorphism, socionomic, sex ratio and body weight in primates. Nature, 269: 797-800. DOI: 10.1038/269797a0

Colwell R.K. (2000) Rensch's Rule Crosses the Line: Convergent Allometry of Sexual Size Dimorphism in Hummingbirds and Flower Mites. The American Naturalist, 156(5): 495-510. DOI: $10.1086 / 303406$

Dale J., Dunn P.O., Figuerola J., Lislevand T., Székely T. \& Whittingham L.A. (2007) Sexual selection explains Rensch's rule of allometry for sexual size dimorphism. Proceedings of the Royal Society of London B: Biological Sciences, 274: 2971-2979. DOI: 10.1098/rspb.2007.1043

Darwin C. (1859) On the Origin of Species by Means of Natural Selection. London: John Murray. $502 \mathrm{p}$.

Darwin C. (1871) The Descent of Man and Selection in Relation to Sex. London: John Murray. $475 \mathrm{p}$.

Diniz-Filho J.A.F., Bini L.M., Rodriguez M.A., Rangel T.F.L. \& Hawkins B.A. (2007) Seeing the forest for the trees: partitioning ecological and phylogenetic components of Bergmann's rule in European Carnivora. Ecography, 30(4): 598-608. DOI: 10.1111/j.0906-7590.2007.04988.x

Emlen D.J., Marangelo J., Ball B. \& Cunningham C.W. (2005) Diversity in the weapons of sexual selection: horn evolution in the beetle genus Onthophagus (Coleoptera: Scarabaeidae). Evolution, 59(5): 1060-1084. DOI: 10.1554/04-642

Fairbairn D.J. (1997) Allometry for Sexual Size Dimorphism: Pattern and Process in the Coevolution of Body Size in Males and Females. Annual Review of Ecology and Systematic, 28: 659-687. DOI: 10.1146/annurev.ecolsys.28.1.659

Fairbairn D.J. (2007) Introduction: the enigma of sexual size dimorphism (p. 27-37). In: Fairbairn D.J., Blanckenhorn W.U. \& Székely T. (Eds). Sex, Size and Gender Roles: Evolutionary Studies of Sexual Size Dimorphism. Oxford: Oxford University Press. 280 p. DOI: 10.1093/acprof:oso/9780199208784.003.0001

Fairbairn D.J. (2013) Odd Couples: Extraordinary Differences between the Sexes in the Animal Kingdom. Princenton: Princenton University Press. 312 p. 
Fairbairn D.J., Blanckenhorn W.U. \& Székely T. (2007) Sex, Size and Gender Roles: Evolutionary Studies of Sexual Size Dimorphism. Oxford: Oxford University Press. 280 p. DOI: 10.1093/acprof:oso/9780199208784.001.0001

Felsenstein J. (1985) Phylogenies and the comparative method. The American Naturalist, 125(1): $1-15$.

Geist V. (1998) Deer of the World: Their Evolution, Behaviour, and Ecology. Mechanicsburg, PA: Stackpole Books. 421 p.

Gohli J. \& Voje K.L. (2016) An interspecific assessment of Bergmann's rule in 22 mammalian families. BMC Evolutionary Biology, 16(222). DOI: 10.1186/s12862-016-0778-x

Hassanin A., Delsuc F., Ropiquet A., Hammer C., Jansen van Vuuren B., Matthee C., Ruiz-Garcia M., Catzeflis F., Areskoug V., Nguyen T.T. \& Couloux A. (2012) Pattern and timing of diversification of Cetartiodactyla (Mammalia, Laurasiatheria), as revealed by a comprehensive analysis of mitochondrial genomes. Comptes Rendus Biology, 335(1): 32-50. DOI: 10.1016/j.crvi.2011.11.002

Huang S., Drake J.M., Gittleman J.L. \& Altizer S. (2015) Parasite diversity declines with host evolutionary distinctiveness: A global analysis of carnivores. Evolution, 69: 621-630. DOI: 10.1111/evo.12611

Isaac J.L. (2005) Potential causes and life-history consequences of sexual size dimorphism in mammals. Mammal Review, 35: 101-115. DOI: 10.1111/j.1365-2907.2005.00045.x

Jarman P. (1983) Mating system and sexual dimorphism in large, terrestrial, mammalian herbivores. Biological Review, 58: 485-520. DOI: 10.1111/j.1469-185X.1983.tb00398.x

Kappeler P.M. \& van Schaik C.P. (2004) Sexual Selection in Primates New and Comparative Perspectives. Cambridge: Cambridge University Press. 300 p.

Lindenfors P., Gittleman J.L. \& Jones K.E. (2007) Sexual size dimorphism in mammals (p. 16-26). In: Fairbairn D.J., Blanckenhorn W.U. \& Székely T. (Eds). Sex, Size and Gender Roles: Evolutionary Studies of Sexual Size Dimorphism. Oxford: Oxford University Press. 280 p.

Martinez P. \& Bidau C. (2016) A re-assessment of Rensch's rule in tuco-tuco (Rodentia: Ctenomydae: Ctenomys) using a phylogentic approach. Mammalian Biology, 81(1): 66-72. DOI: 10.1016/j.mambio.2014.11.008

Martínez P.A., Amado T.F. \& Bidau C.J. (2014) A phylogenetic approach to the study of sexual size dimorphism in Felidae and an assessment of Rensch's rule. Ecosistemas, 23: 27-36. DOI: 10.7818/ECOS.2014.23-1.05

Martinez P.A., Marti D.A., Molina W.F. \& Bidau C.J. (2013) Bergmann rule across the Equator: a case study in Cerdocyon thous. Journal of Animal Ecology, 82(5): 997-1008. DOI: 10.1111/1365-2656.12076

Martinez P.A., Pia M.V., Behachar I.A., Molina W.F. \& Montoya-Burgos J.I. (2018) The contribution of neutral evolution and adaptive processes in driving phenotipic divergence in a model mammalian species, the Andean fox Lycalopex culpaeus. Journal of Biogeography, 45(5): 1114-1125. DOI: 10.1111/jbi.13189

Martinez P.A., Zurano J.P., Amado T.F., Penone G., Betancur-R R., Bidau C.J. \& Jacobina U.P. (2015) Chromosomal diversity in tropical reef fishes is related to body size and depth range. Molecular Phylogenetics and Evolution, 93: 1-4. DOI: 10.1016/j.ympev.2015.07.002

McPherson F.J. \& Chenoweth P.J. (2012) Mammalian sexual dimorphism. Animal Reproduction Science, 131: 109-22. DOI: 10.1016/j.anireprosci.2012.02.007

Miller C.W. (2013) Sexual Selection: Male-male Competition (p. 641-646). In: Losos J.B., Baum D.A., Futuyma D.J., Hoekstra H.E., Lenski R.E., Moore A.J., Peichel C.L., Schluter D. \& Whitlock M.C. (Eds). The Princenton Guide of Evolution. Princenton: Princenton University Press. 853 p.

Moran S. \& Poulin R. (1998) Density, body mass and parasite species richness of terrestrial mammals. Evolutionary Ecology, 12(6): 717-727. DOI: 10.1023/A:1006537600093

Nowak R.M. (1999) Walker's Mammals of the World. Baltimore: John Hopkins University Press. $1936 \mathrm{p}$. 
Olalla-Tárraga M.A., Torres-Romero E.J., Amado T.F. \& Martinez P.A. (2015) Phylogenetic path analysis reveals the importance of niche-related biological traits on geographic range size in mammals. Global Change Biology, 21: 3194-3196. DOI: 10.1111/gcb.12971

Payne J. \& Francis C. (1985) A Field Guide to the Mammals of Borneo. Malaysia: Sabah Society. $332 \mathrm{p}$.

Pérez-Barbería F.J., Gordon I.J. \& Pagel M. (2002) The origins of sexual dimorphism in body size in ungulates. Evolution, 56: 1276-1285. DOI: 10.1111/j.0014-3820.2002.tb01438.x

Peters R.H. (1983) The Ecological Implications of Body Size. New York: Cambridge University Press. 329 p.

Piross I.S., Harnos A. \& Rózsa L. (2019) Rensch's rule in avian lice: contradictory allometric trends for sexual size dimorphism. Scientific Reports, 9: 7908. DOI: 10.1038/s41598-019-443705

Plard F., Bonenfant C. \& Gaillard J.M. (2011) Revisiting the allometry of antlers among deer species: male-male sexual competition as a driver. Oikos, 120(4): 601-606. DOI: 10.1111/j.1600-0706.2010.18934.x

Rangel T.F., Colwell R.K., Graves G.R., Fucikova K., Rahbek C. \& Diniz-Filho J.A.F. (2015) Phylogenetic uncertainty revisited: implications for ecological analyses. Evolution, 69: 13011312. DOI: $10.1111 /$ evo.12644

R Core Team (2018) R: A language and environment for statistical computing. R Foundation for Statistical Computing. Available in: http://www.R-project.org

Reiss M.J. (1989) The Allometry of Growth and Reproduction. Cambridge: Cambridge University Press. 200 p. DOI: https://doi.org/10.1017/CBO9780511608483

Rensch B. (1950) Die Abhangigkeit der relativen Sexualdifferenz von der Korpergrosse. Bonner Zoologische Beiträge, 1: 58-69.

Revell L.J. (2012) phytools: an R package for phylogenetic comparative biology (and other things). Methods in Ecology and Evolution, 3: 217-223. DOI: 10.1111/j.2041210X.2011.00169.x

Smith F.A. \& Lyons S.K. (2011) How big should a mammal be? A macroecological look at mammalian body size over space and time. Proceeding Royal Society B, 366: 2364-2378. DOI: 10.1098/rstb.2011.0067

Smith F.A. \& Lyons S.K. (2013) Animal Body Size: Linking Pattern and Process Across Space, Time, and Taxonomic Group. Chicago: The University of Chicago Press. 280 p.

Sokal R.R. \& Rohlf F.J. (1995) Biometry: The Principles and Practice of Statistics in Biological Research. $3^{\circ}$ edition. New York: W.H. Freeman and Com. 887 p.

Stevens R.D. \& Platt R.N. (2015) Patterns of secondary sexual size dimorphism in New World Myotis and a test of Rensch's rule. Journal of Mammalogy, 96(6): 1128-1134. DOI: 10.1093/jmammal/gyv120

Stuart-Fox D.M. \& Ord T.J. (2004) Sexual selection, natural selection and the evolution of dimorphic coloration and ornamentation in agamid lizards. Proceeding Royal Society B, 271: 2249-2255. DOI: DOI: 10.1098/rspb.2004.2802

Tobias J.A., Montgomerie R. \& Lyon B.E. (2012) The evolution of female ornaments and weaponry: social selection, sexual selection and ecological competition. Philosophical Transaction of Royal Society London, 367: 2274-2293. DOI: 10.1098/rstb.2011.0280

Wiles G.J., Buden D.W. \& Worthington D.J. (1999) History of introduction, population status, and management of Philippine deer (Cervus mariannus) on Micronesian islands. Mammalia, 63(2): 193-215. 